\title{
A SIMPLE PROPOSAL FOR ULTIMATE SEISMIC DEMAND EVALUATION OF MOMENT RESISTING STEEL FRAMES
}

\author{
鋼構造ラーメン骨組の終局地震荷重効果評価手法の簡略化
}

\author{
Praveen KHANDELWAL*, Kenichi $O H I^{* *}$ and Peiyu FANG ${ }^{* * *}$ \\ プラヴィーン カンデルワル，大井謙一，方 沛 宇
}

\begin{abstract}
A simple proposal for ultimate seismic demand evaluation of multi-degree-of-freedom moment resisting steel frames is developed from limit analysis and first order reliability method (FORM). First, a procedure is proposed for 'vibration mode-failure mode' integrated analysis, wherein the restoring force characteristics are represented by a global convex yield polyhedron model, instead of a set of member hysteresis based models usually adopted in the inelastic structural analysis. Then, FORM is extended to seismic design in the form of 'random pushover analysis', to choose an appropriate number of failure modes to be considered in the vibration mode-failure mode analysis. Random pushover shows a positive correlation with the deterministic analytical procedures and can be further used to determine the lateral load patterns for pushover by the nonlinear static procedures. A six-storey two-bay frame is taken for case study and is analysed by the proposed methods for three ground motions and an impulse. By comparing the results with the member-hysteresis based analytical procedures, this study indicates that the proposed simple methods can serve as a good tool for seismic demand evaluation for practical purposes.
\end{abstract}

Keywords: demand evaluation, inelastic response, yield polyhedron, planar steel moment resisting frame, design point 要求評洒、弾塑性応答、降伏多面体、鋼構造平面ラーメン、設計点

\section{INTRODUCTION}

The emphasis in seismic resistance design is shifting from 'strength' to 'performance' following the damage and collapse of numerous structures during recent earthquakes. Gradually, performance based designs are becoming a part of code provisions with the publication of FEMA-273 [1] in USA and Enforcement Order and Regulations after Building Standard Law of Japan was revised in 1998 [2]. At the same time, it may be fair to say that simple and efficient methods for capturing the essential/important features affecting the performance have not been adequately developed. The research summarised in this paper focuses on the development of design friendly methods for seismic demand evaluation of multi-degree-of-freedom moment resisting steel frames. As a simplification over member hysteresis based analytical procedures, an approach for vibration mode-failure mode integrated analysis is proposed, wherein the failure modes are obtained by the limit analysis of the structure. Random pushover approach, based on FORM, is presented to choose an appropriate number of important/dominant failure modes, for structures having large number of failure modes, for further consideration in the vibration-mode failure mode analysis. A suggestion is made on the issue of load pattern selection, for detection of weak/ local collapse mechanism by nonlinear static pushover procedures, through examination of the design points of the failure modes. Application of the proposed methods is discussed for a six-storey two-bay frame by studying its response to El Centro (NS), Hachinohe (EW), Fukiai (NS) ground motions and an impulse. Considering the practical difficulties in explaining the physical meaning of some of the proposed ideas, a two-storey single-bay frame is also taken to illustrate the basic principles. Results are compared with the memberhysteresis based detailed analytical models to judge the validity of the proposed simplified methods.

\section{DESCRIPTION OF FRAME MODELS}

A six-storey two-bay frame [3] is taken to study the application of the proposed concepts. The storey height is $3.75 \mathrm{~m}$ and span of each bay is $6 \mathrm{~m}$. The frame is shown in Fig. 1 and the member properties and floor weights are shown in Table 1 and 2, respectively. The modulus of elasticity and yield stress for steel is taken as $205 \mathrm{GPa}$ and $235 \mathrm{MPa}$, respectively. A constant modal-damping ratio of $2 \%$ is considered for all the vibration modes. The vibration periods are shown in Table 3.

\footnotetext{
Note: A part of this research was presented in Ref. [13].

* Graduate Student, University of Tokyo

** Assoc. Prof., Institute of Industrial Science, University of Tokyo, Dr. Eng

*** Executive Manager, DYNA Inc.
}

東京大学大学院 大学院生
東京大学生産技術研究所 助教授・工博
(侏)ダイナ 取締役 
The failure modes considered under horizontal loads are shown in Fig. 2 and have been drawn based on the experience. These include local storey collapse mechanisms and combined mechanisms. Locations of the plastic hinges are assumed at the top and bottom ends of the columns, which have undergone side sway, and at the floor beams end connected with the side columns. At the junction of the floor beams and the central column, plastic hinges are assumed in the beams or in the columns, whichever is having the least summation of the plastic moment capacities at the junction.

The total weight of the frame is $3326.4 \mathrm{kN}$ and yield base shear coefficient is 0.11 . The frame is analysed for El Centro (NS), 1940, Hachinohe (EW), 1968, Fukiai (NS), 1995 ground motions and an impulse of $0.75 \mathrm{~m} / \mathrm{sec}$ velocity. The details of the ground motions are shown in Table 4.

Basic principles are illustrated with the help of a two-storey single-bay frame as shown in Fig. 3. The ratio of span (L) to storey height $(\mathrm{H})$ and mass at $2^{\text {nd }}$ floor to roof are 1.6 and 1.5464 , respectively. The relative member properties are shown in Table 5 . The total weight (W) of the frame is $484 \mathrm{kN}$. $2 \%$ modal damping is assumed for both vibration modes. The elastic vibration periods for the first and second mode are 1.23 and 0.472 seconds, respectively. The frame is analysed for El Centro (NS), 1940 ground motion with peak ground acceleration as $0.3 \mathrm{~m} / \mathrm{sec}^{2}$. The failure modes are shown in Fig. 4.

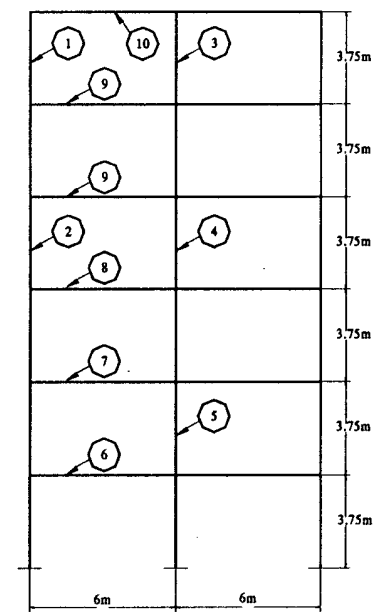

Fig.1 Six-Storey Two-Bay Frame

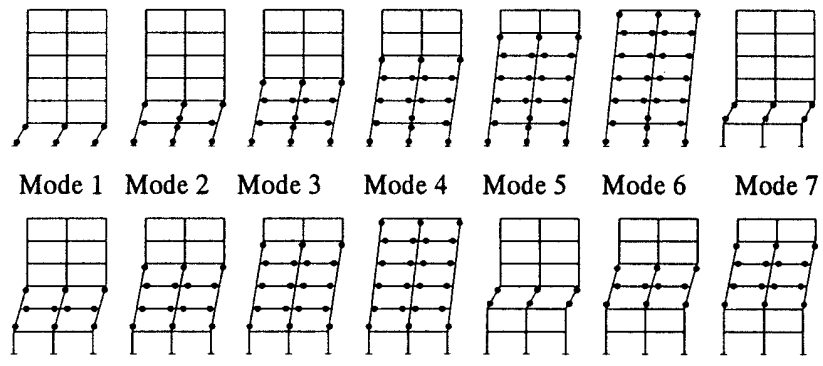

Mode 8 Mode 9 Mode 10 Mode 11 Mode 12 Mode 13 Mode 14

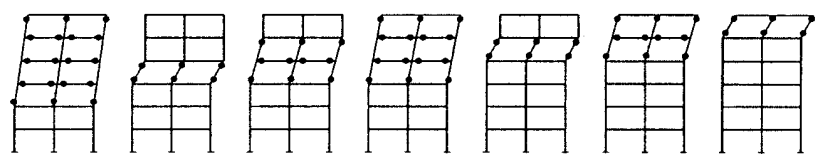

Mode 15 Mode 16 Mode 17 Mode 18 Mode 19 Mode 20 Mode 21

Fig. 2 Collapse Modes for six-storey two-bay frame

Table 1 - Member Properties

\begin{tabular}{|l|l|r|}
\hline $\begin{array}{l}\text { Mem. } \\
\text { ID }\end{array}$ & $\begin{array}{l}\text { Moment } \\
\text { of Inertia } \\
\left(10^{-8} \mathrm{~m}^{4}\right)\end{array}$ & $\begin{array}{l}\text { Plastic } \\
\text { Moment } \\
\text { Capacity } \\
\text { (kN. m) }\end{array}$ \\
\hline 1 & 2492 & 83.19 \\
\hline 2 & 8091 & 194.35 \\
\hline 3 & 5696 & 151.11 \\
\hline 4 & 11260 & 247.46 \\
\hline 5 & 14920 & 301.51 \\
\hline 6 & 23130 & 307.15 \\
\hline 7 & 16270 & 239.47 \\
\hline 8 & 11770 & 188.94 \\
\hline 9 & 8356 & 147.58 \\
\hline 10 & 3892 & 86.25 \\
\hline
\end{tabular}

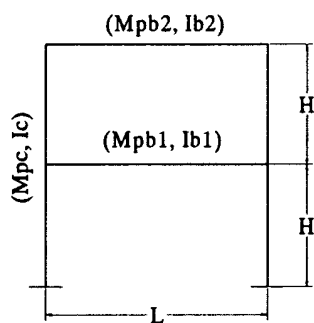

Fig. 3. Two Storey Single Bay Frame

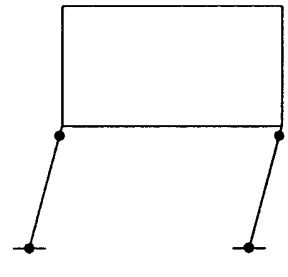

$1^{\text {st }}$ Storey Local Collapse

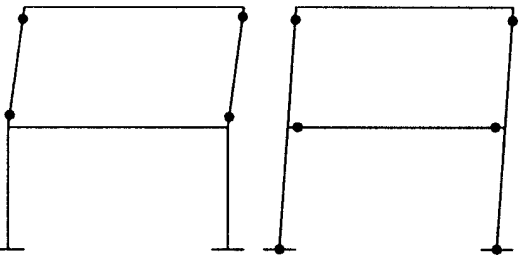

$2^{\text {nd }}$ Storey Local Collapse Combined Mechanism

Fig. 4 - Failure Modes of the two-storey frame

Table 2-Floor
Weights
\begin{tabular}{|l|c|}
\hline Floor & $\begin{array}{c}\text { Weight } \\
(\mathrm{kN})\end{array}$ \\
\hline Roof & 380.4 \\
\hline 6 & 589.2 \\
\hline 5 & 589.2 \\
\hline 4 & 589.2 \\
\hline 3 & 589.2 \\
\hline 2 & 589.2 \\
\hline
\end{tabular}

Table 3-Vibration Periods (Sec)

\begin{tabular}{|l|r|}
\hline Mode & $\begin{array}{c}\text { Time } \\
\text { Period }\end{array}$ \\
\hline 1 & 2.57 \\
\hline 2 & 0.98 \\
\hline 3 & 0.57 \\
\hline 4 & 0.43 \\
\hline 5 & 0.31 \\
\hline 6 & 0.23 \\
\hline
\end{tabular}

Table 4 - Details of Ground Motions

\begin{tabular}{|l|l|l|l|}
\hline $\begin{array}{l}\text { Ground } \\
\text { Motion }\end{array}$ & Earthquake & $\begin{array}{l}\text { Peak Ground } \\
\text { Acceleration } \\
\text { (in gravity } \\
\text { acceleration) }\end{array}$ & $\begin{array}{l}\text { Duration } \\
\text { (Sec) }\end{array}$ \\
\hline $\begin{array}{l}\text { El Centro } \\
\text { (NS) }\end{array}$ & $\begin{array}{l}\text { Imperial Valley, } \\
1940\end{array}$ & 0.325 & 10 \\
\hline $\begin{array}{l}\text { Hachinohe } \\
\text { (EW) }\end{array}$ & $\begin{array}{l}\text { Tokachi - Oki, } \\
1968\end{array}$ & 0.186 & 30 \\
\hline Fukiai (NS) & $\begin{array}{l}\text { Hyogoken - } \\
\text { Nanbu, 1995 }\end{array}$ & 0.700 & 20 \\
\hline
\end{tabular}

Table 5-Member

Properties

\begin{tabular}{|l|l|}
\hline $\begin{array}{l}\text { Property } \\
\text { ratio }\end{array}$ & Value \\
\hline $\mathrm{Mpb1/Mpc}$ & 1.179 \\
\hline $\mathrm{Mpb2/Mpc}$ & 1.036 \\
\hline $\mathrm{Ib} 1 / \mathrm{Ic}$ & 3.353 \\
\hline $\mathrm{Ib} 2 / \mathrm{Ic}$ & 1.561 \\
\hline
\end{tabular}

Mp- Plastic moment capacity

I-Moment of Inertia 


\section{VIBRATION MODE-FAILURE MODE ANALYSIS}

In order to visualise failure modes of a structure in a nonlinear seismic analysis, a simple procedure for vibration mode-failure mode integrated analysis is proposed. The response of the structure is confined within a convex region bounded on all sides by the failure planes (referred to as yield polyhedron hereafter). Fig. 5 shows yield polyhedron for the two-storey frame. The $\mathrm{f} 1$ and $\mathrm{f} 2$ represent the restoring forces (in original space) at the second floor and roof level, respectively. Representation of the restoring force characteristics of the structure by a yield polyhedron model considerably reduces the magnitude of the analysis, compared with member-hysteresis based models usually employed in the inelastic analysis. The likely failure modes can be drawn based on the experience or stochastic limit analysis using compact procedure $[4,5]$ may be used for complex situations. Sequence of yielding before mechanism formation i.e. partial yielding is ignored in the yield polyhedron model. As the analysis is performed in the modal coordinates, the failure modes can be transformed to the modal coordinates using the following transformation equation:

$$
\{f\}=[\phi]^{-1}\{r\}
$$

where, $\{r\},\{f\}$ and $[\phi]$ are modal restoring force vector, original restoring force vector and modal participation matrix, respectively. Participation matrix $[\phi]$ is obtained from the modal analysis of linear elastic system and is normalised such that the participation factor for any mode is unity. Each column vector of $[\phi]^{T^{-1}}$ represents the lateral loading pattern of each vibration mode and remains constant during the analysis. Equation of motion for seismic excitation is integrated by numerical methods, such as the central difference method, in the modal coordinates. The locus of restoring forces can move within or tangentially on the boundary of the yield polyhedron, as shown in Fig. 6 for the two-storey frame. The r1 and $\mathrm{r} 2$ are components of $\{\mathrm{r}\}$ and represent the restoring forces for the first and second mode, respectively.

In the inelastic state, the plastic component of the deformation is computed from the normality rule of plasticity.

Yield polyhedron approach enables a quick examination of the seismic response in terms of the failure modes of the structure, which is quite informative and helpful in understanding critical/ important design situations and in taking remedial measures.

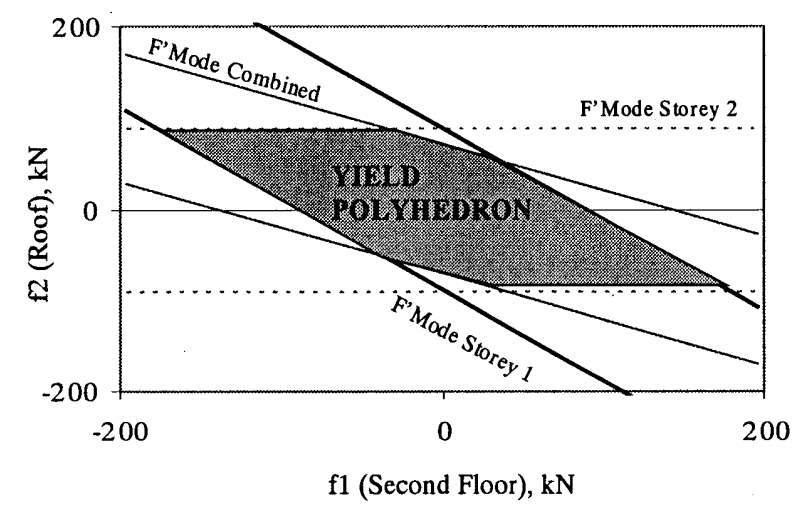

Fig. 5 Global Yield Polyhedron in Original Restoring Force Space

\section{RANDOM PUSHOVER ANALYSIS}

\section{Seismic Loading Model}

As the ground motion varies randomly in time, mean value or expected value of modal restoring forces is taken as zero and the vibration modes are considered independent. In usual notations:

$$
\begin{aligned}
& E\left(r_{j}\right)=\bar{r}_{j}=0 ; \quad E\left(r_{i} r_{j}\right)=0 \quad(i \neq j) \\
& \sigma_{r j}=c m_{j} S_{a j}
\end{aligned}
$$

where, $r_{j}, m_{j}^{*}$ and $\sigma_{r j}$ are the modal restoring force, effective modal mass and standard deviation of the modal restoring force, for the jth vibration mode, respectively. $c$ is a constant which is determined from the relationship between the standard deviation of modal restoring force at arbitrary points in time and its mean extrema and is taken as one-third for all the modes [6, 7]. $S_{a j}$ is the ordinate of acceleration response spectra, which is dependent on period and damping of the jth vibration mode (refer Fig. 7).

\section{Reduction of Failure Modes}

Stochastic limit analysis, based on FORM, is applied for identification of more likely failure modes. It is assumed that the loads and resistances are independent of each other. The performance function $(g)$ for a failure mode can be written in terms of the work done by the resistance capacity and load effects as:

$$
g=\sum_{i=1}^{m} M_{p i}\left|\theta_{p i}\right|-\sum_{j=1}^{n} a_{j} r_{j}=g_{0}-\sum_{j=1}^{n} a_{j} r_{j}
$$

where, $m$ and $n$ are number of element resistance (moment) capacity and number of vibration modes respectively. The work done by the resistance capacity is represented by $\sum_{i=1}^{m} M_{p i}\left|\theta_{p i}\right|$, where $M_{p i}$ is the basic variable of element moment capacity and $\left|\theta_{p i}\right|$ represents the rotation of the corresponding plastic hinge. The work done by the load effects is expressed in the modal coordinates and is represented by $\sum_{j=1}^{n} a_{j} r_{j}$, where $a_{j}$ is the jth modal component of plastic deformation compatible with before mentioned plastic hinge rotations.

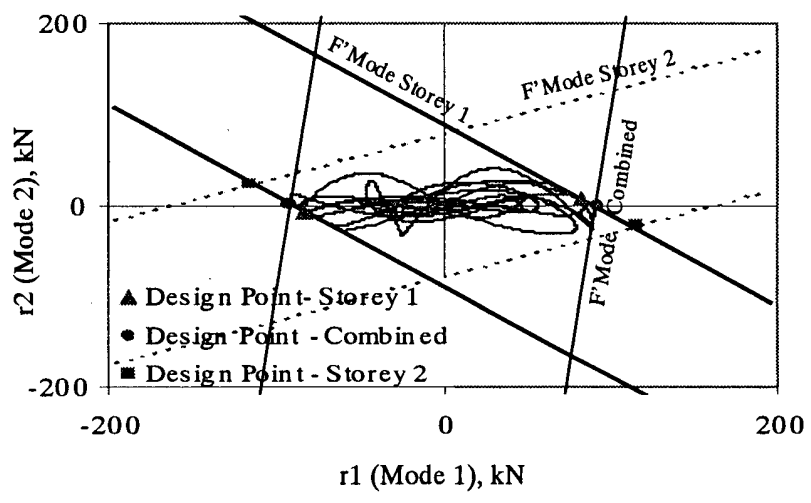

Fig. 6 Locus of Restoring Force and Design Points in Modal Space 
Mean value of $g$

$$
\mu_{g}=\sum_{i=1}^{m} \overline{M_{p i}}\left|\theta_{p i}\right|-\sum_{j=1}^{n} \bar{r}_{j} a_{j}
$$

Standard deviation

$$
\sigma_{g}=\sqrt{\sum_{i=1}^{m} \sigma_{m p i}^{2} \theta_{p i}^{2}+\sum_{j=1}^{n}\left(\sigma_{r j}\right)^{2}\left(a_{j}\right)^{2}}
$$

$\bar{M}_{p i}, \bar{r}_{j}$ are mean values and $\sigma_{m p i}, \sigma_{r j}$ are standard deviations of load and resistance capacity, respectively.

Reliability index $\quad \beta=\frac{\mu_{g}}{\sigma_{g}}=\frac{g_{0}}{\sigma_{g}}$

A lower reliability index indicates higher probability of failure. In our view, failure modes with probability less than about $10 \%$ of the most likely $\left(\beta_{\min }\right)$ failure mode can be excluded from further analysis. Alternatively, failure modes with $\beta \geq \beta_{\min }+\Delta$ can be neglected. For Gaussian distribution if $\beta_{\min } \geq 1.4, \Delta$ equal to unity would be adequate. In addition, the maximum number of failure modes considered should preferably be limited to the number of vibration degrees of freedom, to avoid possibility of ill conditioning during dynamic analysis. For structures with very large numbers of potential failure modes, mutual correlation between the failure modes should be considered, as many of them may be partially correlated. PNET [8], which stands for probabilistic network evaluation technique was applied for the six-storey frame. The correlation coefficient between the two failure modes $a$ and $b$, whose performance functions are denoted by $g_{a}=g_{0 a}-\sum_{j=1}^{n} a_{j} r_{j}, g_{b}=g_{0 b}-\sum_{j=1}^{n} b_{j} r_{j}$ respectively, can be written as:

$$
\rho_{a b}=\frac{\mathrm{E}\left[\left(g_{a}-\mathrm{E}\left(g_{a}\right)\right)\left(g_{b}-\mathrm{E}\left(g_{b}\right)\right)\right]}{\sigma_{a g} \sigma_{b g}}
$$

where, $\sigma_{a g}, \sigma_{b g}$ are standard deviations of $g_{a}, g_{b}$ respectively. Resistance capacity has been considered deterministic in the analysis. Under such a condition, equation (8) can be further simplified as:

$$
\rho_{a b}=\frac{\sum_{j=1}^{n} a_{j} b_{j} \sigma_{r j}{ }^{2}}{\sqrt{\left(\sum_{j=1}^{n} a_{j}^{2} \sigma_{r j}{ }^{2} \sum_{j=1}^{n} b_{j}{ }^{2} \sigma_{r j}{ }^{2}\right)}}
$$

Failure modes with correlation coefficients more than a demarcating correlation $\rho_{0}$ are unified and represented by a single failure mode having lowest reliability index among them. As the failure probabilities range from $10^{-1}$ to $10^{-3}, \rho_{0}=0.70$ appear appropriate [8]. However, adoption of such a low value resulted in the elimination of the majority of the failure modes for the six-storey frame. A value of $\rho_{0}=0.97$ was found to give satisfactory result. Table 6 and 7 lists the reliability index of the failure modes for the six-storey and two-storey frame, respectively. Table 8 lists the failure modes obtained by PNET for the six-storey frame.

\section{Lateral Load Pattern by Design Point of Failure Modes}

Issue of load pattern selection is critical for performance evaluation by nonlinear static pushover procedures. At present, pushover by using invariant load patterns such as proportional to first mode shape or a uniform load pattern is in practice [9]. Static pushover analysis using such load patterns may lead to misleading predictions particularly when localised yielding mechanism have formed. Some adaptive load patterns [10] have been suggested, but none have proven to be universally applicable, as higher mode effects are not accounted. On the other hand, load pattern obtained from the design point of failure mode, as explained next, appear to be free from such limitations.

Design point of a failure mode is the most likely failure point on its surface. Fig. 8 shows the design points of the failure modes in relation to reliability index for the two-storey frame. The design point of the most likely failure mode represents the design point of the yield polyhedron and this design point lies on the surface of the yield polyhedron e.g. design point of first storey failure mode in Fig.8. The design points for some failure modes may not lie on the surface of the yield polyhedron such as the design point for the second storey collapse as shown in Fig. 8. Most likely failure point of a failure mode lies with minimum distance from origin [11] in the standard variable space. Standard variables are random variables with mean value as zero and standard deviation being unity and can be written as:

$$
u_{m p i}=\frac{M_{p i}-\bar{M}_{p i}}{\sigma_{m p i}}, \quad u_{r j}=\frac{r_{j}-r_{j}}{\sigma_{r j}}
$$

Performance function in terms of standard variables can be written as:

$$
G=\sum_{i=1}^{m}\left(\sigma_{m p i} u_{m p i}+\overline{M_{p i}}\right)|\theta|_{p i}-\sum_{j=1}^{n}\left(\sigma_{r j} u_{r j}+r_{j}^{-}\right) a_{j}
$$

Design point $u^{*}$ is the closest point from origin in the standard variable space, i.e.

$$
u_{m p i}=-\beta \frac{\sigma_{m p i}\left|\theta_{p i}\right|}{\sigma_{g}}, \dot{u_{r j}}=\beta \frac{\sigma_{r j} a_{j}}{\sigma_{g}}
$$

Components of design points in the original space are

$$
M_{p i}^{\dot{0}}=\sigma_{m p i} \dot{u}_{m p i}+\dot{M}_{p i}, \quad r_{j}^{*}=\sigma_{r j} \dot{u}_{r j}+\dot{r}_{j}=\sigma_{r j} \dot{u}_{r j}=\frac{\beta}{\sigma_{g}}\left(\sigma_{r j}\right)^{2} a_{j}
$$

Fig. 6 shows the design points of the failure modes for the twostorey frame. It can be seen that the design point for the most likely failure mode, i.e. first storey, is traced by the locus of modal restoring force in the dynamic analysis. As it is difficult to visualise the similar situation for the six-storey frame, the coordinates of five nearest points (on the loci of the modal restoring force) from the design point of fifth storey (most likely) collapse are plotted. Fig. 9 shows such a plot for the El Centro ground motion. For the purpose of clarity, only first four modal restoring force coordinates ( $r 1$ through $\mathrm{r} 4$ ) are plotted for the design point and five nearest points in Fig. 9. Table 9 shows the coordinates of the fifth storey design point, nearest and average of five nearest (from the design point) on the loci, in terms of the modal restoring forces. By examining Fig. 9 and Table 9, it is fair to say that the loci in the dynamic analysis passed close to the design point. The coordinates of the design point shear, as listed in Table 9, indicate dominance of the first two modes. Similar results were obtained for other ground motions. These observations suggest that design point represents a realistic load profile and also incorporates higher mode effects.

The load profiles in the original coordinates can be obtained by using equation (1) and the coordinates of the design point in the modal restoring force space. Design point of the fifth storey collapse was used as the initial load profile in the compact procedure. At the end of the iterations, same collapse mechanism was observed which is shown in Fig. 10. This suggests that pushover using design point loading of the most likely collapse mechanism would be able to detect it and therefore, design point loading profile can be used for the purpose of nonlinear static pushover analysis. 

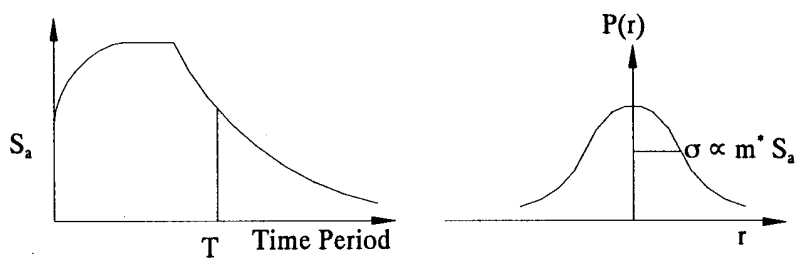

Acceleration Response Spectra

Definition of standard deviation

Fig. 7 Random Loading Model

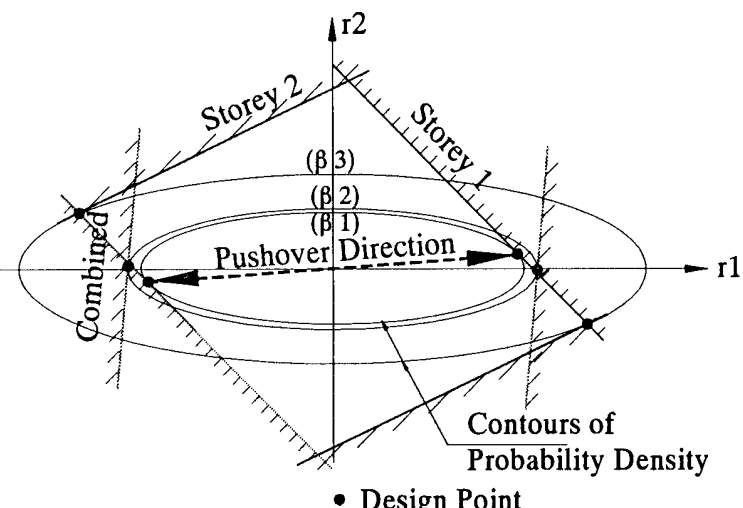

Fig.8 Design Point of Failure Modes

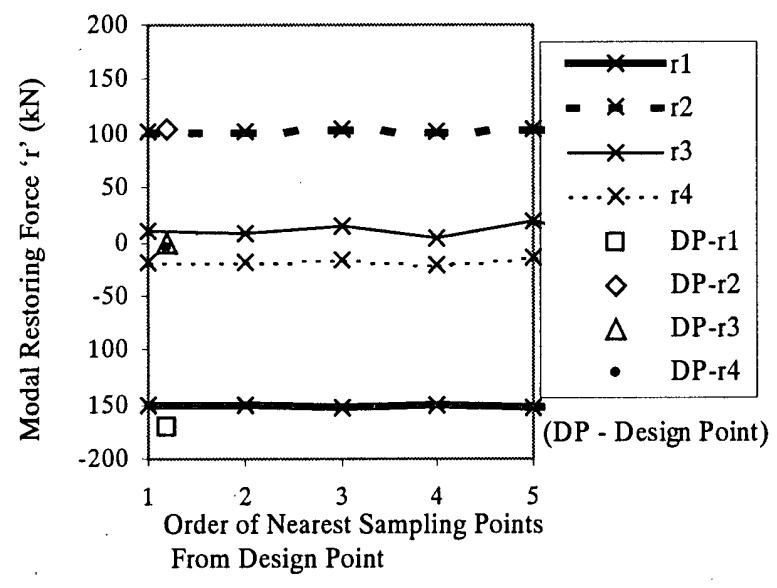

Fig. 9 Load Profile Near Design Point of Fifth Storey Collapse (El Centro)

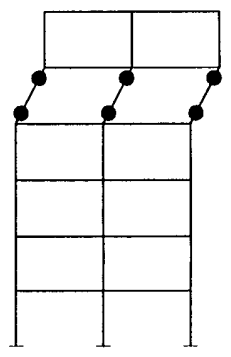

Fig. 10 Failure Mode Traced By Compact Procedure
Table 6 Reliability Index for Failure Modes of SixStorey Frame

\begin{tabular}{|l|r|r|r|r|}
\hline \multirow{2}{*}{$\begin{array}{l}\text { Failure } \\
\text { Mode }\end{array}$} & \multicolumn{5}{|c|}{ Reliability Index $\beta$} \\
\cline { 2 - 5 } & $\begin{array}{l}\text { El } \\
\text { Centro }\end{array}$ & $\begin{array}{l}\text { Hachi- } \\
\text { nohe }\end{array}$ & Fukiai & Impulse \\
\hline 1 & 1.912 & 1.232 & 1.439 & 2.026 \\
\hline 2 & 1.943 & 1.204 & 1.450 & 2.080 \\
\hline 3 & 1.939 & 1.152 & 1.437 & 2.034 \\
\hline 4 & 1.986 & 1.142 & 1.475 & 2.037 \\
\hline 5 & 1.955 & 1.102 & 1.455 & 1.977 \\
\hline 6 & 2.110 & 1.184 & 1.574 & 2.127 \\
\hline 7 & 2.189 & 1.324 & 1.618 & 2.261 \\
\hline 8 & 2.020 & 1.178 & 1.498 & 2.063 \\
\hline 9 & 2.011 & 1.147 & 1.505 & 2.036 \\
\hline 10 & 1.865 & 1.051 & 1.395 & 1.878 \\
\hline 11 & 2.054 & 1.156 & 1.530 & 2.070 \\
\hline 12 & 2.392 & 1.398 & 1.799 & 2.367 \\
\hline 13 & 2.107 & 1.228 & 1.609 & 2.129 \\
\hline 14 & 1.803 & 1.050 & 1.358 & 1.851 \\
\hline 15 & 2.027 & 1.186 & 1.505 & 2.098 \\
\hline 16 & 2.715 & 1.668 & 2.088 & 2.723 \\
\hline 17 & 1.861 & 1.154 & 1.387 & 1.982 \\
\hline 18 & 2.097 & 1.324 & 1.539 & 2.288 \\
\hline 19 & 1.560 & 1.057 & 1.138 & 1.712 \\
\hline 20 & 1.911 & 1.360 & 1.416 & 2.230 \\
\hline 21 & 2.273 & 1.982 & 1.835 & 2.623 \\
\hline
\end{tabular}

Table 7 Reliability Index for Failure Modes of Two-Storey

Frame

\begin{tabular}{|l|l|}
\hline Failure Mode & $\begin{array}{l}\text { Reliability } \\
\text { Index }\end{array}$ \\
\hline First Storey & 1.67 \\
\hline Second Storey & 2.68 \\
\hline Combined mode & 1.79 \\
\hline
\end{tabular}

Table 8 Failure Modes by PNET For Six-Storey Frame

\begin{tabular}{|l|l|}
\hline $\begin{array}{l}\text { Seismic } \\
\text { Motion }\end{array}$ & Failure Modes \\
\hline El Centro & $19,14,17,10,20,1$ \\
\hline Hachinohe & $14,19,5,3,2,21$ \\
\hline Fukiai & $19,14,17,10,3,1$ \\
\hline Impulse & $19,14,5,17,1,8$ \\
\hline
\end{tabular}

Table 9- Design Point Coordinates for Fifth Storey Local Collapse and Dynamic Analysis Loci in the Vicinity (El Centro)

\begin{tabular}{|l|l|l|l|l|}
\hline $\begin{array}{l}\text { Modal } \\
\text { restoring } \\
\text { force }\end{array}$ & $\begin{array}{l}\text { Design } \\
\text { Point } \\
\text { Coord- } \\
\text { inates } \\
(\mathrm{kN})\end{array}$ & $\begin{array}{l}\text { Nearest } \\
\text { Point } \\
\text { on Loci } \\
(\mathrm{kN})\end{array}$ & $\begin{array}{l}\text { Average } \\
\text { of five } \\
\text { nearest on } \\
\text { Loci }(\mathrm{kN})\end{array}$ & $\begin{array}{l}\text { Design } \\
\text { Point } \\
\text { Shear } \\
(\mathrm{kN})\end{array}$ \\
\hline R1 & -170 & -152 & -152 & 85 \\
\hline R2 & 105 & 103 & 103 & 79 \\
\hline R3 & 0 & 11 & 11 & 0 \\
\hline R4 & -5 & -18 & -18 & 4 \\
\hline R5 & 2 & 3 & 3 & 1 \\
\hline R6 & 0 & 2 & 2 & 0 \\
\hline Distance from origin (kN) & \multicolumn{5}{|c|}{200} & 184 & 184 & \\
\hline \multicolumn{5}{|c|}{} \\
\hline
\end{tabular}




\section{COMPARISION OF RESULTS}

The six-storey frame is analysed for El Centro (NS), Hachinohe (EW), Fukiai (NS) ground motions and an impulse of $0.75 \mathrm{~m} / \mathrm{sec}$ velocity, by the proposed methods, referred to as RA hereafter. The impulse level is selected from consideration of similar order of deformation pattern in comparison with other ground motions. The energy input spectra and acceleration response spectra are shown in Figs. 11 and 12, respectively. To confirm the validity of RA, results have been compared with a member hysteresis based analysis, performed using a computer program DIANA [12] with all members being idealised as elastic perfectly plastic. As there is vast amount of data, response histories of the top storey, the bottom storey and the most damaged storey i.e. fifth have shown for comparison. Fig. 13 shows the response histories of the storey drifts. Peak response values and time variations are well simulated.

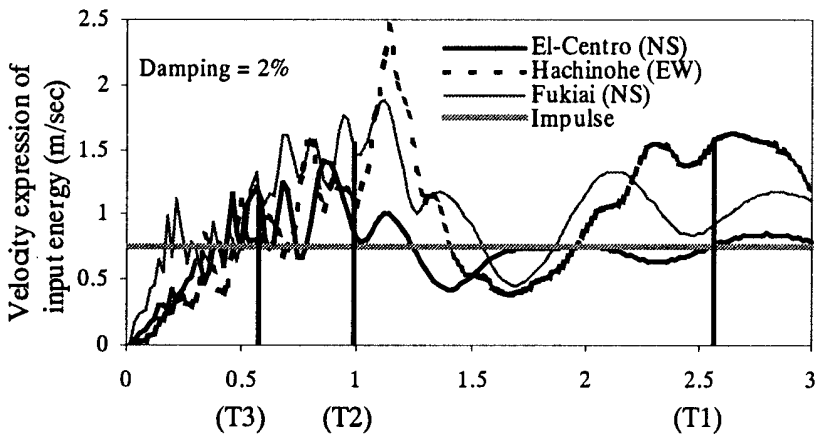

Time Period (Sec.)

Fig. 11 Energy Input Spectra (in velocity expression)
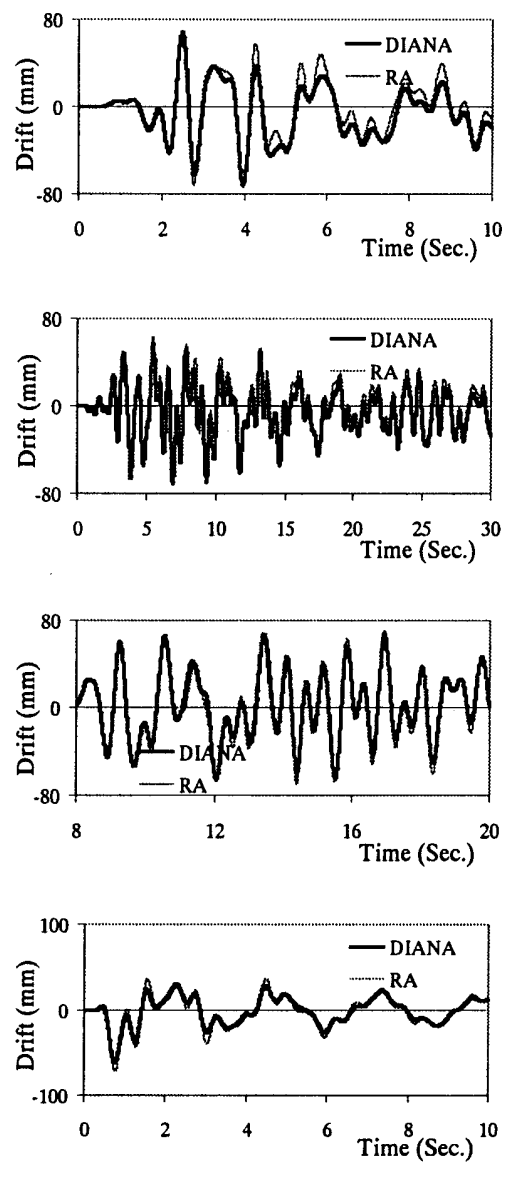

(a) Sixth Storey Drift
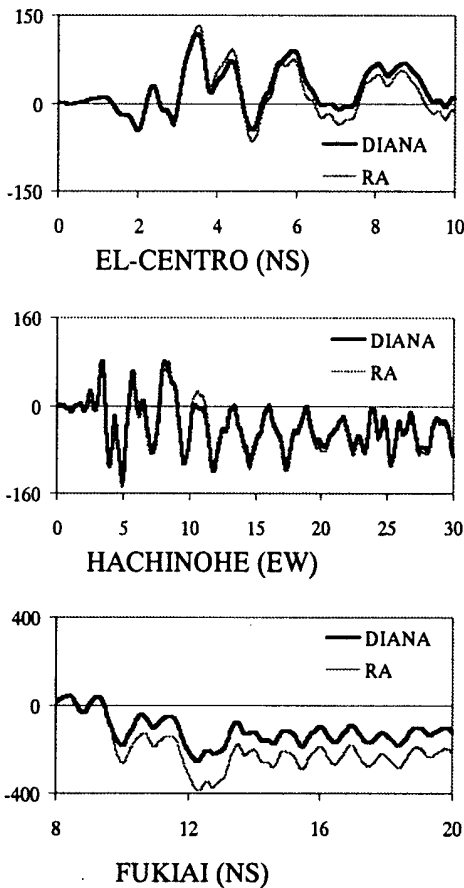

Fig. 14 compares the hysteresis loops of the storey shear $\mathrm{v} / \mathrm{s}$ storey drifts. RA provides close approximations to DIANA. However, little shifts in the storey drifts appear in some cases. Fig. 15 compares the envelopes of floor displacements, storey drifts and storey shears. Peak floor displacements are well simulated. Fifth storey appear as the weak/ local collapse mechanism, which coincides with the most likely failure mode indicated by the random pushover analysis. RA has provided consistently good results for the peak fifth storey drift, which is the most important response quantity. For other storey drifts, simulation by RA can be considered satisfactory. In general, peak storey shear estimation appears to be conservative. As an overall view, the proposed methods provide consistently good prediction of response quantities in all cases of seismic excitations.

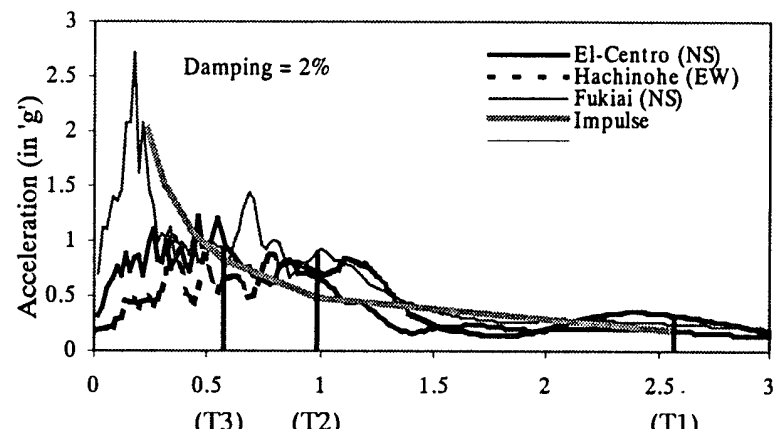

(T3) (T2)

(T1)

Time Period (Sec)

Fig. 12 Acceleration Response Spectra
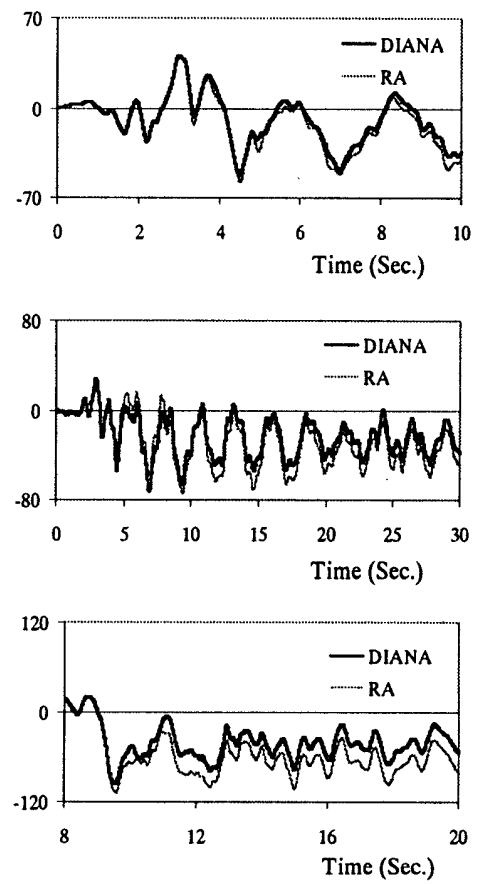

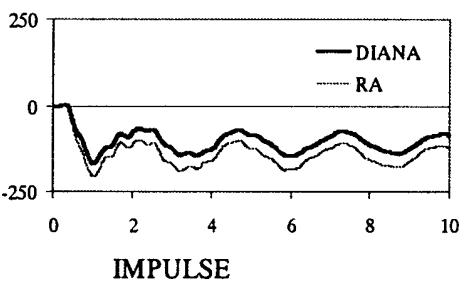

(b) Fifth Storey Drift

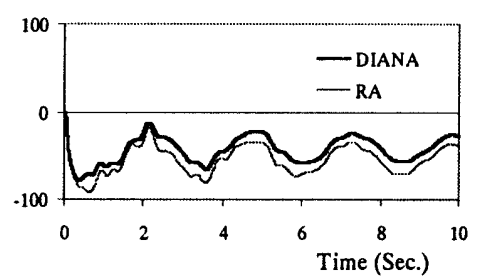

(c) First Storey Drift
Fig. 13 Response History of Storey Drifts 

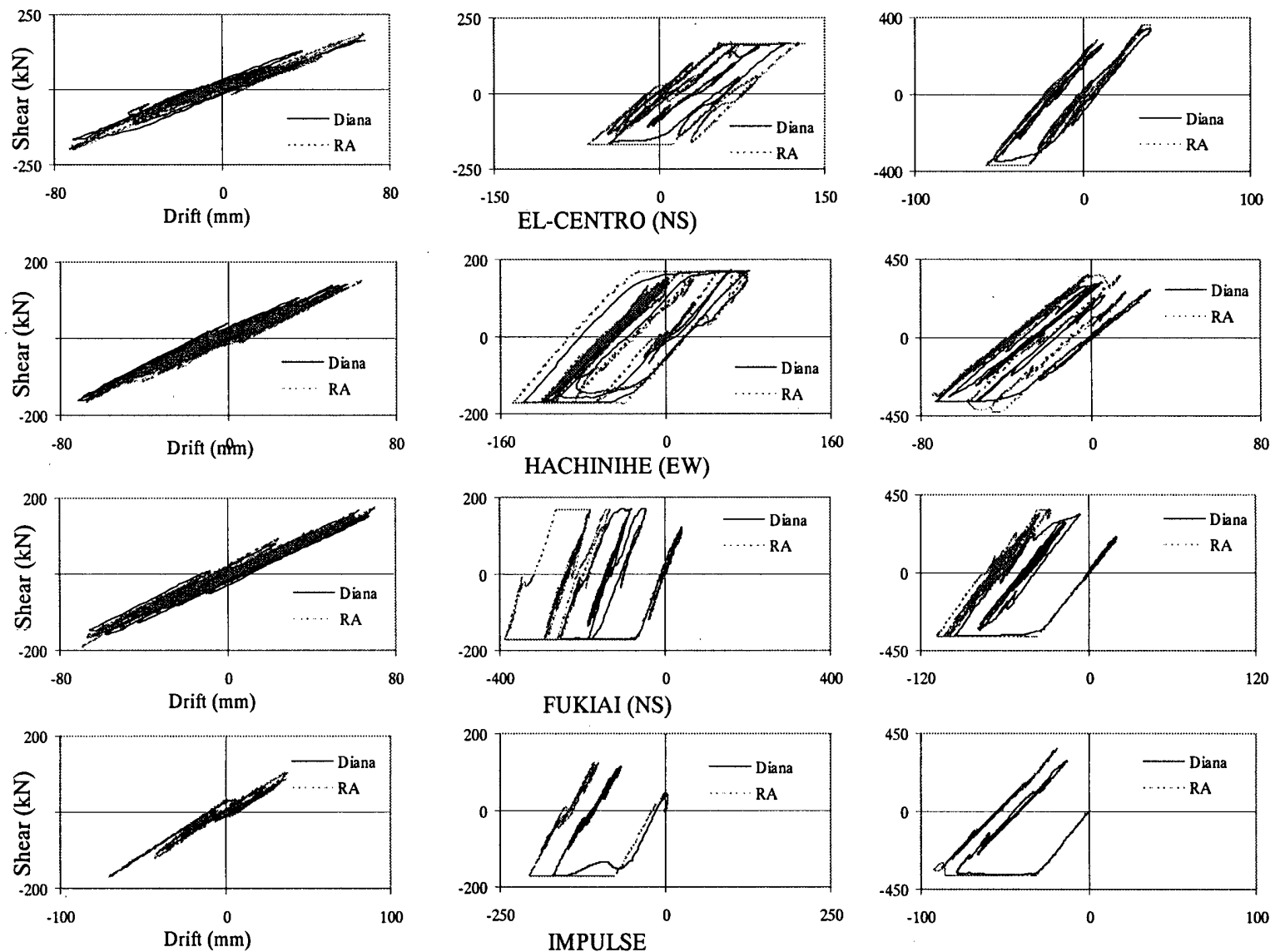

Fifth Storey Shear v/s Drift

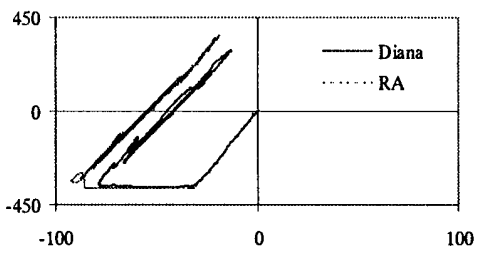

Sixth Storey Shear v/s Drift

Fig. 14 Hysteresis Loops of Storey Shear v/s Storey Drift
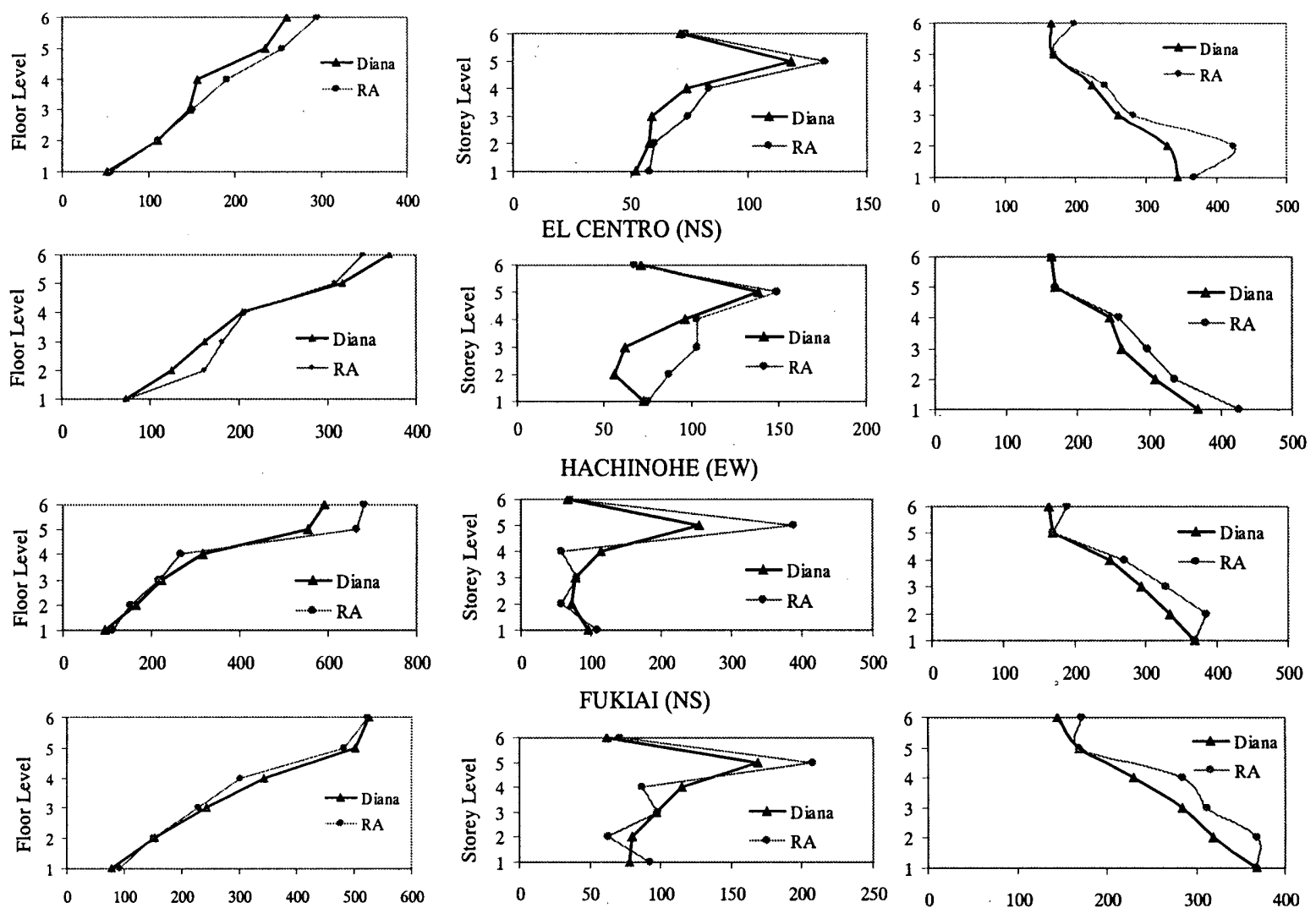

(a) Floor Displacements (mm)

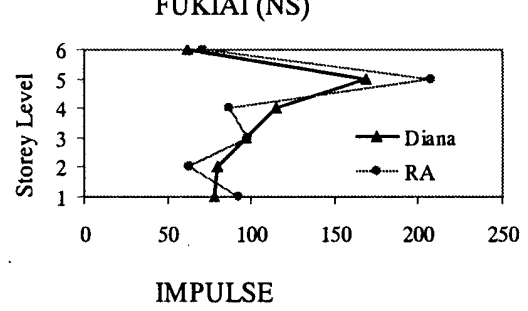

(b) Storey Drift (mm)

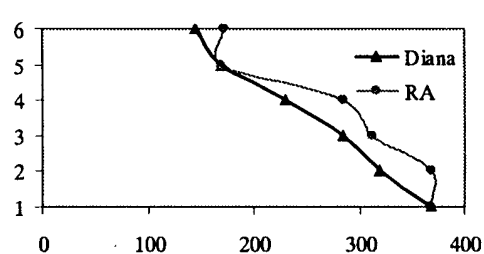

(c) Storey Shear $(\mathrm{kN})$

Fig 15 Envelope of Response Quantities 


\section{CONCLUSIONS}

A simple and design friendly, seismic demand evaluation procedure is proposed for multi-degree-of freedom moment resisting steel frames. The salient features are as follows:

1. A simplified global yield polyhedron model represents the restoring force characteristics of the structure.

2. Random pushover approach is proposed to choose stochastically dominant failure modes.

3. The lateral load profile obtained from the design point of the most likely failure mode can be used for pushover in the nonlinear static procedures.

The validity of the proposed concepts was judged by comparing the response of a six-storey two-bay frame, to El Centro (NS), Hachinohe (EW), Fukiai (NS) ground motions and an impulse, with member hysteresis based analysis procedures. The proposed procedure provided consistently good results for the response quantities of interest.

The ideas proposed in this paper lay emphasise on simplicity as well as generality and are expected to help the practising engineer, who has limited resources and analytical tools to carry out his responsibilities.

\section{REFERENCES}

1. FEMA, NEHRP Guidelines for the seismic rehabilitation of buildings, FEMA-273, Federal Energy Management Agency, USA, 1997

2. Building Standard Law of Japan revised, 1998

3. Chen, W.F. and Toma, S., Advanced Analysis of Steel Frames, CRC Press, 1994, pp. 341-343

4. Ohi, K., Stochastic Limit Analysis of Framed Structures, Proc. of JCOSSAR' 91, pp. 675-678, JSCE, Nov. 1991 (In Japanese)
5. Sun, H., Ohi, K. and Takanashi, K., A Proposal and Verification about Plastic Design Process with Target Collapse Mechanism for Structures, Proc. of $7^{\text {th }}$ ICOSSAR, Nov. 1997.

6. Davenport, A.G., Note on the Distribution of the Largest Value of a Random Function with Application to Gust Loading, Proceedings of the Institution of Civil Engineers, Vol. 28, 1964, pp. 187-196

7. Shibata, A., New Earthquake Resistant Structural Analysis, Morikita Press Co. Ltd., 1993, pp. 188-191 (In Japanese)

8. Ang, A.H.S. and Tang, W.H., Probability Concepts in Engineering Planning and Design Volume II Decision, Risk and Reliability, John Wiley \& Sons, pp. 504-506, 1984

9. Krawinkler, H. and Seneviratna, G.D.P.K., Pros and Cons of a pushover analysis for seismic performance evaluation, Engineering Structures 20, 452-464 (1998)

10. Bracci, J.M., Kunnath, S.K. and Reinhorn, A.M., Seismic performance and retrofit evaluation for reinforced concrete structures, Journal of Structural Engineering, ASCE 1997, 123(1), 3-10

11. Shinozuka, M., Basic Analysis of Structural Safety, Journal of Structural Engineering, ASCE, Vol.109, No.3, March 1983,pp. 721740

12. Dynamic Inelastic ANAlysis of steel frames, a private program coded by S.H. Gao and K.OHI, The University of Tokyo, 1987

13. Ohi, K., Fang, P. and Khandelwal, P., Dynamic Analysis with Reduced Modes by Yield Polyhedron Model for Inelastic Frames Part 1 and Part 2, Summaries of Technical Papers of Annual Meeting of AlJ, Sep. 2000, Vol. B-1, pp. 429-432 (Part 2 in Japanese) 


\section{1.はじめに}

構造設計の性能規定化が提唱されている。米国ではすでに FEMA273 に性能設計の概念を取り入れており、日本でも 1998 年の建築基準 法の改定に伴い、様々の性能検証ルートが許容されるようになったが、構 造物の各種の能力 (Capacity) が要求性能 (Demand)を満足しているか どうかを検証するという枠組みは、様々な検証法で共通と考えられる。本研 究は、鋼構造ラーメン骨組に対する要求性能、特に終局地震荷重効果を 動的解析によって評価する手法を、グローバルな視点で大幅に簡素化す る解析手法を提案するものである。

本研究で提案する手法は、鋼構造多層ラーメン骨組の安全領域を凸降 伏多面体モデルで表し、振動方程式を古典的規準振動モード座標で解く 簡略化応答解析手法である。多層骨組の膨大な崩壊モードについては、 考慮すべき重要な崩壊モードを、ランダム複合モード載荷下での近似信 頼性解析法(FORM)に基づく確率極限解析を予め実行しておくことにより、 崩壊モード数を適切な数に低減しておく手法を提案寸る。この予備解析手 法は、多層骨組の静的弾塑性増分解析において、高次振動を適切に考 慮した荷重パターンを設定するためにも用いることができる。

\section{2. 解析対象の铜構造ラーメン骨数モテル}

研究解析対象骨組は文献 3)の Benchmark study に用いられている、 層高 $3.75 \mathrm{~m}$ 、スパン $6 \mathrm{~m}$ の 6 層 2 スパン鉄骨造骨組である。弾性 1 次固 有周期は 2.57 秒、降伏ベースシア係数は 0.11 及び減衰は全振動モード における $2 \%$ に一ード減衰を仮定した。対象骨組の諸元を図 1 及び表 1 、 $2 、 3$ に示す。

部材耐力を確定としているので、水平荷重に対して考慮寸る6層骨組の 崩壊メカニズム形を図 2 に示すものに限定する。また提案する解析手法の 物理的意味を簡明に説明するため、2 層 1 スパン骨組モデルの例題を示 し、その諸元及び崩壊モードを図 $3 、 4 、$ 表5に示す。

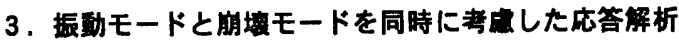

従来の部材レベルの骨組地震応答解析では、各部材毎に復元力特性 モデルを仮定して、忘答解析を遂行するので計算が繁雑になる。しかし本 研究で提案する手法は、骨組の安全領域を、崩壤メカニズム形を重要なも ののみに限定した凸降伏多面体モデルでモデル化し、それを、式(1)より 通常座標からモード座標に変換して、応答解析を行う。

図 5 に前述の 2 層 1 スパン骨組の凸降伏多面体モデルを通常の各階 床位置の復元力 (水平力) 座標で示している。この凸降伏多面体モデルを 用いて行った El Centro (NS) 1940 に対する応答解析結果を、図 6 に モード復元力空間での復元力点の軌道で表している。本解析では、一般 化された完全弾塑性モデルが使用され、上記の降伏多面体の内部では弾 性挙動が仮定されるとともに、降伏面上の塑性変形增分は降伏面の法線 則にしたがう。

\section{4. ランタム・ブッシュオーパー解析}

\section{ランダム椱合モード荷鈿モテル}

弾性地震荷重効果の静的荷重モデルとして、古典的規準モードの荷重 基底ベクトルにモード乗数を乗じて線形結合したランダム複合モード荷重 モデルを仮定する。モード乗数の平均值は0とし、標準偏差は式(3)、各次 の有効質量と設計用加速度応答スペクトル值の積に比例させる。比例定 数は、確率過程の任意時点における標準偏差とある継続時間内の平均最
大值との関係を参考にして、暫定的に $1 / 3$ と仮定している。また異なるモ ード乗数間の相関は考慮していない。

\section{朋壤モードの省略}

ここでは、崩壊メカニズム形成を仮の限界状態として、各崩壊メカニズム に対する性能関数として式(4)を用いて解析を行う。また、性能関数の平均 値と標準偏差は、荷重と部材耐力の平均値と標準偏差を用いて式(5)、(6) により評価し、各崩壊メカニズムに対する性能関数の信頼性指標 $\beta$ を式 (7)によって求める。なお本論文の範囲では、部材耐力を確定とする。前述 の 6 層 2 スパン骨組に対して、表 4 に示寸 4 種の地震波とインパルス波 に対応する 5 種類の加速度応答スペクトルによって各次の荷重モード乗 数の標準偏差を設定して行った予備解析結果を表 6 に示している。

本予備解析では、崩壊メカニズムに対応する信頼性指標值が、最も小さ い指標値に1を加えたもの以上となるような崩壊メカニズムを暫定的に省略 している。この設定は望ましい簡略化の程度に依存する。

また骨組の規模が大きく崩壊メカニズムの数が多い場合では、似通った 崩壊メカニズムの性能関数は大きな相関を持つ。本解析では PNET 法を 用いて、極めて相関の高い崩壊メカニズムは統合化して解析を行う。式(9) によって2つの崩壊メカニズムの相関係数を求め、相関係数の值が 0.97 以上となるものを暫定的に統合化している。表 8 に、以上の条件を満足寸 る最終的に考慮すべき崩壊メカニズムを地震波別に示している。いずれの 場合も図2に示した 21 個の崩壊メカニズムを6つの崩壊メカニズムに集約 寸ることになる。

\section{設枓点による荷至パターンの造定（觧的弾望性解析用）}

上記の予備解析は、静的弹塑性增分解析における荷重パターンの選定 にも役立てることができる。すなわち、骨組に発生しやすい崩壊メカニズム に応じて、その崩壊メカニズムが発生するとすれば最も局所的な確率密度 の高くなる荷重パターンを FORM における設計点として評価する。荷重 モード乗数の標準空間において設計点を求めるプロセスを式(10)から式 (13)に示しているが、 2 層 1 スパン骨組の場合の各メカニズムに対応する 設計点を図8に示している。6 層 2 スパン骨組については、El Centro 地 震波に対して信頼性指標値が最小となる No.19 の崩壊メカニズムの設計 荷重パターンが、応答解析においても実現していることを図 9、表 9 で確 認している。

\section{解析桔果の比校（峌的彈望性応答解析）}

上記のように崩壤モード数を6個に低減した凸降伏多面体モデルによる 簡略化応答解析結果と、部材レベルで通常の塑性ヒンジの発生を考慮し た骨組地震応答解析による応答解析結果との比較を行う。4つの入力地 震波及びインパルス波の応答スペクトルを図 $11 、 12$ に示寸。図 13 に層 間変位の時刻歴、図 14 に各層の履歴曲線、図 15 に最大相対変位、最 大層間変位及び最大層せん断力の分布を比較しているが、若干の誤差は 認められるものの、大局的にはよく一致している。

\section{5. まとめ}

本研究では鋼構造ラーメン骨組における終局地震荷重効果をグローバ ルな視点で簡略に評価する応答解析手法を提案した。提案した解析手法 を 6 層 2 スパン骨組に適用し、その結果を従来の部材モデルによる詳細 な弹塑性地震応答解析結果と比較し、そのグローバルな弾塑性応答を追 跡できることを確認した。

（2000年11月 10 日原稿受理，2001年 2 月 14 日採用決定） 